\title{
Perancangan Video Iklan Destination Branding Kabupaten Kediri
}

\author{
Hen Dian Yudani \\ Program Studi Desain Komunikasi Visual, Fakultas Seni dan Desain \\ Universitas Kristen Petra Surabaya, Indonesia \\ Email: hendian@peter.petra.ac.id
}

\begin{abstract}
Abstrak
Kabupaten Kediri memiliki wilayah yang cukup luas. Kediri memiliki beberapa potensi untuk dijual dan bersaing dengan kota yang lain diantaranya budaya dan pariwisata. Destination branding Kediri dengan tagline "Kediri Lagi" memiliki beberapa media promosi. Setiap media memiliki kesatuan konsep yang baik. Media video merupakan salah satu media yang dirancang untuk promosi Kediri. Perancangan video iklan ini merupakan wujud media yang harus dipunyai karena kelebihan media ini memiliki gambar dan suara dimana cukup efektif sebagai media promosi Kediri. Tahapan perancangan yang digunakan adalah tahapan dalam membuat video yaitu tahap praproduksi, produksi dan paskaproduksi. Video iklan sebagai hasil dari perancangan ini merupakan video iklan yang dipublish di media online. Video iklan Kediri cukup efektif dalam mempromosikan wilayah Kediri yang memiliki potensi wisata alam, peninggalan sejarah dan budaya lokal.
\end{abstract}

Kata kunci: Video ilkan, destination branding, pariwisata Kabupaten Kediri.

\begin{abstract}
Kediri Regency has a large area. Kediri has some potential to sell and compete with other cities such as culture and tourism. Destination branding Kediri with tagline "Kediri Lagi" has some promotional media. Each media has a good unified concept. Media video is one of the media designed for Kediri promotion. Advertising video is a form of media that must be possessed because of the advantages of this media have picture and sound where quite effective as aKediri media campaign. Stages of design that used are the stages in making a video, preproduction stage, production and postproduction. Video ads as a result of this design is a video advertisement that is published in online media. Kediri advertising video is quite effective in promoting Kediri region that has the potential of natural tourism, historical relics and local culture.
\end{abstract}

Keywords: Video ads, destination branding, Kediri tourism.

\section{Pendahuluan}

Kabupaten Kediri merupakan suatu wilayah yang mempunyai potensi yang besar dalam berbagai aspek terlebih dibidang pariwisata. Potensi daerah seperti halnya produk atau jasa, diberi merek agar mempunyai ciri sebagai pembeda dengan daerah lain. Bersamaan dengan era otonomi daerah, berbagai daerah lain juga melakukan hal yang sama untuk berupaya menonjolkan identitasnya sehingga berbeda dengan daerah yang lain. Upaya Pemerintah Daerah Kabupaten Kediri membangkitkan potensi daerah melalui kegitaan destination branding merupakan hal yang sedang dilakukan saat ini. Destination branding sendiri merupakan konsep branding daerah tujuan, bisa berbentuk negara maupun daerah, namun konsep ini biasa digunakan dalam pariwisata (The brandna magazine. Volume 2 edition, may-june 2008).
Berkaitan hal tersebut Dinas Pariwisata Kabupaten Kediri bekerjasama dengan Program Studi Desain Komunikasi Visual sudah melaksanakan penelitian guna merumuskan destination branding yang sesuai dengan potensi yang dimiliki Kabupaten Kediri. Potensi yang dimiliki daerah ini dapat dikatakan paling lengkap dibanding dengan daereah lain. Keberhasilan mempromosikan Kabupaten Kediri sendiri terletak dari kuatnya sinergi, kesatuan, konsistensi implementasi dari branding pada berbagai media seperti katalog, brosur dan media elektronik lainnya dimana media video iklan sebagai salah satu media yang akan digunakan.

Hasil dari rumusan destination branding dengan tagline "Kediri lagi" tersebut yang dibuat sebagai panduan dalam melakukan promosi untuk mengkomunikasikan potensi dan keunggulan 
Kabupaten Kediri kepada masyarakat luas. Keberhasilan sebuah destination branding juga dudukung oleh media yang digunakan. Salah satu media pendukung yang digunakan adalah media video iklan. Video iklan ini mampu mengkomunikasikan informasi atau pesan melalui modalitas gambar dan suara sehingga memiliki kemampuan lebih dibandingkan dengan media lain. Menurut Azhar Arsyad film/video adalah gambar-gambar didalam sebuah frame yang diproyeksikan proyektor sehingga terlihat seperti gambar hidup. Video yang bergerak tersebut memiliki daya tarik tersendiri yang dalah hal ini mampu mengkomunikasikan pesan lebih efektif.

Dinas Pariwisata Kabupaten Kediri berencana untuk memakai video iklan sebagai salah satu media utama dalam memperkenalkan dan mempromosikan Kabupaten Kediri. Perencanaan yang dilakukan dalam pembuatan video iklan merujuk pada rumusan destination branding yang telah dibuat sebelumnya supaya pesan yang dikomunikasikan sama. Penerapan teori dan teknik dalam perancangan video iklan dilaksanakan untuk menghasilkan video yang menggugah emosi sebagai bagian proses persuasif.

\section{Destination Branding}

Destination branding menurut Ritchie, J.R. and Ritchide, J.B (1998) merupakan nama, simbol, logo atau bentuk grafis lainnya yang membedakan dan mengidentifikasi daerah tujuan, memberi harapan akan sebuah perjalanan yang tak terlupakan secara unik yang diasosiasikan dengan daerah tersebut. Dalam hal ini destination branding yang diangkat adalah destination branding Kediri dengan tagline 'Kediri Lagi". Selain itu menurut Kaplanidou and Vogt (2003) dikatakan bagaimana konsumen mempersepsikan daerah tujuan dalam pikiran mereka, yaitu bagaimana menciptakan elemen brand yang berbeda dan bagaimana mengkomunikasikan elemen ini melalui komponen brand.

Empat hal yang diperoleh dari Destination Branding:

1. Membentuk persepsi publik terhadap tempat itu.

2. Mengemas tempat tersebut secara selektif dan estetik.

3. Membuat tempat tujuan dapat berdiri di tengah persaingan pariwisata global sehingga dapat bersaing.

4. Membentuk pengalaman pariwisata.

\section{Video Iklan/Promosi}

Menurut M.Suyanto (2005) video merupakan bagian dari gambar-gambar yang berurutan disebut frame dengan ukuran 24 frame/second (FPS = Frame Per Second). Gambar-gambar tersebut kemudian diproyeksikan di layar dan ditambahkan dengan objek animasi atau teks. Format file dalam video diantaranya: 1. Audio video interleave (AVI), standar video pada lingkungan windows. 2. Motion overlay video (MOV), 3. Motion picture expert group (MPEG), format video yang biasa digunakan dalam VCD. 4. Real Video dikembangkan oleh Real Media. 5. Shockwave (Flash) dikembangkan oleh Macromedia, format shockwave membutuhkan sebuah komponen tambahan untuk dimainkan. Audio visual merupakan media dengan unsur suara dan unsur gambar. Jenis media tersebuut mempunyai kemampuan lebih baik karena memiliki suara dan gambar. Dalam media audio visual memiliki dua unsur yang saling menyatu yaitu audio dan visual.

Promosi/iklan menurut Kotler (2003:22), merupakan cara perusahaan untuk melakukan komunikasi melalui pesan-pesan yang dibuat untuk menstimulasi terjadinya kesadaran (awareness), ketertarikan (interest), dan berakhir dengan tindakan pembelian (purchase) yang dilakukan oleh pelanggan terhadap produk atau jasa perusahaan. Sedang menurut Lamb Hair dan Mc-Daniel (2001:116), promosi merupakan komunikasi dari penjual yang menginformasikan, membujuk, dan mengingatkan calon pembeli suatu produk untuk mempengaruhi pendapat mereka. Dari beberapa pemahaman diatas apabila digabungkan antara video dan promosi/iklan, video iklan merupakan sebuah bentuk promosi dalam format video/ gambar gerak.

\section{Metode Perancangan}

Perancangan dilakukan dalam tiga tahapan yaitu tahapan pra-produksi dengan membuat konsep video, penjadwalan, listing equipment dan wawancara untuk mengetahui data awal setting, dan perencanaan casting. Tahap yang kedua adalah tahap produksi untuk mengambil shot-shot gambar. Tahap yang keiga adalah proses editing video, color editing, color grading, rendering dan publishing.

\section{Target Audience}

Secara demografis video iklan "Kediri lagi" ditujukan untuk:

- Target : Masyarakat Indonesia

- Usia : 18-45 Tahun

- Status Ekonomi : Menengah keatas

- Tingkat Pendidikan: Minimal SMA

- Tingkat Pekerjaan : Semua profesi 


\section{Geografis}

Warga Kabupaten Kediri (primer), warga Indonesia \& mancanegara (sekunder)

\section{Psikografis}

Masyarakat yang berpikiran maju, memiliki jiwa petualang dan berjelajah ke suatu wilayah baru.

a. Behavioristik

- Bekerja secara aktif rumah.

- Senang dalam eksplorasi.

\section{Pesan Komunikasi}

Pesan komunikasi untuk pemirsa warga Kabupaten Kediri yaitu Kediri memiliki potensi untuk siap berkembang dan dikembangkan. Pesan komunikasi untuk pemirsa selain warga Kabupaten Kediri yaitu Kediri memiliki berbagai lokasi, obyek, budaya dan masyarakat yang berpotensi sebagai tujuan wisata.

\section{Format Media}

Video iklan harus memiliki format sebagai berikut: Teknologi : digital

Visual : warna

Audio : stereo

Resolusi : Full HD (1920 x 1080 pixels.

Aspect ratio: 16:9-landscape

Codec : H.264 (atau setara)

Durasi : 30 detik (untuk penayangan di televisi/broadcast), 60 detik dan 90 detik (untuk penayangan di jejaring sosial dan event publik/pameran).

\section{Strategi Komunikasi}

Destination branding bertujuan untuk membangun kedekatan emosional dengan pemirsa. Denagn demikian, strategi komunikasi video harus mengedepankan tampilan visual dan audio yang membangkitkan kenangan positif masa lampau, serta menyatukan kenangan tersebut dalam kekinian pemirsa. Semua elemen dikemas dan disajikan dalam alur cerita (narasi) dengan struktur dramatik tiga

\section{Distribusi}

Distribusi dilakukan lewat media jejaring sosial di internet. Faktor yang menjadi pertimbangan pemilihan jalur distribusi tersebut adalah sebagai berikut:

- Jejaring sosial sudah menjadi bagian dari gaya hidup pemirsa sasaran.

- Pemirsa sasaran sudah cukup paham teknologi untuk mengakses jejaring sosial di internet.
- Teknologi jejaring sosial di internet telah memungkinkan penayangan video.

- Jejaring sosial memungkinkan akses video melalui mobile gadget (handphone dan tablet), sehingga memungkinkan video diputar kapanpun dan dimanapun pemirsa berada.

- Sebagian besar jaringan layanan telekomunikasi di Indonesia telah menyediakan layanan koneksi internet cepat dan terjangkau serta memiliki area cakupan sinyal yang cukup luas. Hal ini menjadi faktor penting yang memungkinkan video dalam jejaring sosial di internet dapat diputar dengan baik (streaming).

- Jejaring sosial memungkinkan interaksi dari pemirsa, baik itu berupa komentar maupun like. Hal ini dapat menjadi umpan balik untuk mengevaluasi efektifitas video yang ditayangkan, sekaligus menjadi data yang berguna untuk memahami psikografis pemirsa. Interaksi juga sangat bermanfaat dalam membangun kedekatan emosional dengan pemirsa.

- Jejaring sosial memungkinkan penyebaran video melalui aktifitas sharing. Hal ini mempercepat dalam memperbanyak jumlah pemirsa yang dapat dijangkau.

- Biaya untuk distribusi video di jejaring sosial relatif sangat murah (hanya membutuhkan biaya untuk koneksi ke internet).

Jejaring sosial memiliki karakteristik yang perlu menjadi perhatian penting yaitu bersifat publik. Karakter ini dapat menjadi potensi merugikan jika tidak diantisipasi dan dikelola dengan benar. Hal lain yang juga perlu menjadi perhatian adalah jejaring sosial tersedia dalam dunia maya (internet), sehingga tidak dapat diakses secara langsung oleh modalitas pemirsa. Perlu ada aktifitas di awal yang mengkomunikasikan keberadaan maupun lokasi/link video tersebut kepada pemirsa.

Berdasarkan paparan di atas, distribusi video iklan "Kediri Lagi" melalui jejaring sosial harus mempertimbangkan ketentuan-ketentuan berikut ini:

- Jejaring sosial yang digunakan harus memiliki jumlah pengguna yang banyak dari demografis sasaran pemirsa yang dituju.

- Jejaring sosial yang digunakan harus dapat dijangkau oleh pemirsa dari berbagai negara.

- Jejaring sosial yang digunakan harus memiliki server dengan bandwith yang cukup luas untuk memungkinkan akses konten video dengan lancar.

- Jejaring sosial yang digunakan sebaiknya memiliki reputasi yang baik dari pihak pemirsa sasaran; jejaring sosial tersebut tidak mudah diidentifikasikan dengan konten yang bersifat negatif (misal. pornografi). 
- Jejaring sosial yang digunakan sebaiknya memiliki fitur yang memungkinkan kontrol terhadap interaksi pemirsa (misal. proses sensor terhadap komentar pemirsa).

- Jejaring sosial yang digunakan sebaiknya memiliki fitur yang memungkinkan kontrol terhadap proses distribusi video yang ditayangkan (misal. memungkinkan perlindungan copyright sehingga tidak mudah disalahgunakan oleh pemirsa).

- Sebaiknya menggunakan lebih dari satu jejaring sosial sebagai sumber database video (misal: video diunggah di Youtube dan di Vimeo). Hal ini untuk mengantisipasi keamanan ketersediaan data.

- Video yang diunggah sebaiknya dikelola dalam akun resmi milik pemerintah kabupaten, serta memiliki tim yang bertugas sebagai admin akun.

- Video yang akan ditayangkan harus memiliki format dan ukuran data yang memungkinkan akses dapat dilakukan dengan lancar (cepat) dan memiliki kualitas visual dan audio yang memadai melalui berbagai macam media layar baik yang bersifat stationary (misal. komputer desktop, smart TV) maupun mobile (handphone dan tablet).

- Setelah video ditampilkan dalam jejaring sosial, harus ada aktifitas pantauan yang dilakukan secara berkala (sebaiknya tiap hari) oleh admin. Hal ini untuk menghindari hilangnya video karena diretas dan masalah teknis pada jaringan server.

- Setelah video ditampilkan dalam jejaring sosial, harus ada aktifitas pantauan terhadap komentar pemirsa secara berkala (sebaiknya tiap hari) oleh admin. Hal ini untuk proses sensor terhadap komentar yang kurang pantas (menggunakan kata-kata tidak sopan) dan di luar topik. Selain itu admin perlu melakukan tanggapan terhadap setiap komentar pemirsa, hal ini penting untuk membangun kedekatan emosional dengan pemirsa.

- Perlu ada aktifitas yang mendorong pemirsa untuk berinteraksi yang terkait dengan video yang ditayangkan (misal. lomba membuat video parodi dari video iklan yang ditayangkan).

- Perlu ada aktifitas yang mendorong pemirsa untuk mengunjungi lokasi yang ditayangkan di video iklan tersebut, atau untuk berinteraksi secara langsung dengan orang, benda dan lokasi yang ditayangkan di video iklan tersebut.

- Video yang ditayangkan harus diikuti oleh penayangan video-video berikutnya yang masih relevan dengan konsep destination branding. Hal ini penting untuk menjaga jumlah pemirsa.

\section{Rancangan Video}

Proses perancangan video iklan "Kediri Lagi" secara garis besar dilaksanakan secara berurutan dalam 3 tahapan, yaitu:

1. Pra Produksi, merupakan tahap perencanaan awal yang berfungsi sebagai panduan dalam proses produksi dan paska produksi.

2. Produksi, merupakan tahap perekaman adegan-adegan video

3. Paska Produksi, merupakan tahap merangkai hasil rekaman video menjadi satu kesatuan alur cerita yang siap untuk didistribusikan.

Masing-masing tahapan tersebut meliputi aktifitas-aktifitas dengan rincian sebagaimana paparan berikut.

\section{Premise}

Pemise dari video iklan ini adalah menceeritakan seorang warga yang dituntun pesona masa lalu Kediri untuk menjelajahi pesona masa kini Kediri.

\section{Sinopsis}

Seorang warga di tengah-tengah kelesuan rutinitas keseharian tergelitik oleh kehadiran seorang anak kecil. Usahanya untuk mengejar sang anak tanpa disadari menuntun dirinya untuk menjelajahi setiap potensi pesona Kabupaten Kediri. Potensi yang dikunjungi meliputi potensi keindahan alam, potensi budaya dan potensi industri budidaya hasil alam. Penjelajahannya mencapai klimak dengan pertemuan dengan sang anak di puncak Gunung Kelud. Saat bertemu tersebut baru dia sadari sang anak merupakan representasi kenangan, keceriaan dan cita-cita masa lalunya. Keduanya berpegangan tangan, menatap dengan pasti ke horison, siap melangkah menuju masa depan.

\section{Filosofi cerita}

Kabupaten Kediri memiliki masa lalu yang hebat, hal tersebut merupakan aset dalam menggalang segenap elemen yang terdapat di Kabupaten Kediri untuk menyatu dalam satu misi menuju visi mengembangkan Kabupaten Kediri memiliki masa kini dan masa depan yang hebat.

\section{Treatment}

Adegan $1 \rightarrow$ Sang pemeran utama tergelitik melihat sang anak, penasaran dan mengejar sang anak melewati gang-gang sempit di perkampungan kota.

Adegan $2 \rightarrow$ Sang pemeran utama masuk ke kawasan pasar malam dan bertemu dengan 
berbagai potensi kerajinan dan kuliner hasil budidaya warga Kabupaten Kediri.

Adegan $3 \rightarrow$ Sang pemeran utama masuk ke kawasan suasana alam (air terjun) dan hutan. Bertemu dengan potensi budaya tradisi (wayang Krucil) Kabupaten Kediri.

Adegan $4 \rightarrow$ Sang pemeran utama masuk ke kawasan peninggalan budaya masa lalu dan mengagumi keindahan dan kemegahannya.

Adegan $5 \rightarrow$ Sang pemeran utama mencapai puncak Gunung Kelud, akhirnya bertemu dengan sang anak.

Adegan $6 \rightarrow$ Logo dan tagline Kediri Lagi.

\section{Rancangan pemeran}

Pemeran utama $\rightarrow$ Wanita, usia 19-27 tahun, karakter wajah lokal (kulit kecoklatan, karakter wajah Melayu, rambut lurus), tinggi $165-175 \mathrm{~cm}$, tubuh tegap feminin, langsing (bukan kurus), ekpresi wajah lesu (adegan 1), heran, takjub, terpesona (adegan 2-4), gembira, damai (adegan 5), ekspresi gerak tubuh lesu (adegan 1), aktif, tangkas (adegan 2-4), bebas, lega, tenang, anggun (adegan 5).

Pemeran pembantu $\rightarrow$ Wanita, usia 7-9 tahun, karakter wajah lokal (kulit kecoklatan, karakter wajah Melayu, rambut lurut), tinggi maks. $150 \mathrm{~cm}$, tubuh tegap, bobot sedang, ekspresi wajah tak terlihat (adegan 1-4), gembira, damai (adegan 5), ekspresi tubuh centil (adegan 1-4), bebas, lega, ceria (adegan 5).

Pakaian pemeran utama $\rightarrow$ pakaian dinas kerja (adegan 1), pakaian kasual (adegan 2-4), pakaian anggun (adegan 5).

Pakaian pemeran pembantu $\rightarrow$ pakaian khas penari Jaranan (adegan 1-5).

\section{Lokasi/setting}

Beberapa tempat yang direncanakan menjadi lokasi rekam video adalah sebagai berikut:

- Situs peninggalan budaya: Candi Tegowangi, Candi Surowono, terowongan Surowono dan Arca Totok Kerot (simbol gerbang kerajaan Dhoho/Kediri).

- Obyek industri \& perdagangan: Monumen Simpang Lima Gumul \& obyek disekitarnya (Convention Hall, GPI, monumen kereta api, skate park, amphitheatre, pasar tugu), kompleks industri Gudang Garam.

Selain lokasi terdapat beberapa potensi daerah yang direncanakan menjadi obyek video sebagai berikut:

- Kesenian budaya: Seni Barongan, Seni Jaranan, Tari Kediren, wayang Krucil, wayang Mbah Gandrung.

- Hasil budidaya: budidaya \& kuliner bekicot (Ubalan); budidaya nenas, susu, strawberry
(Dholo); budidaya ikan (Desa Wisata Canggu); rosela (Puhsarang); ternak madu, penyadap getah karet (Desa Wisata Joho); pengusaha tahu GTT; kopi luwak.

- Pengrajin: batik Estri, pengrajin gazebo, pengrajin wayang krucil, pemecah batu (Puhsarang)

Setelah survei diputuskan untuk hasil budidaya, pengrajin dan kesenian akan disatukan dalam satu lokasi. Semua potensi tersebut akan ditemui pemeran utama di adegan 2 (suasana pasar malam). Hal tersebut untuk memungkinkan menampilkan seluruh potensi tersebut dalam durasi yang singkat tanpa mengabaikan pesan komunikasi dan estetika visual.

Potensi budaya masa lalu dipilih Candi Tegowangi berdasarkan pertimbangan estetis visual transisi adegan. Candi tersebut memiliki anak candi yang berundak, sehingga memungkinkan pemeran utama melangkah naik untuk selanjutnya ditransisikan dengan melangkah masuk puncak Gunung Kelud.

Sedangkan untuk potensi keindahan alam hanya akan menampilkan 3 lokasi, yaitu: Air Terjun Dholo, hutan pinus di sekitar kawasan Besuki dan kawah Gunung Kelud. Pemilihan Dholo karena secara visual lebih mampu menampilkan sosok air terjun daripada Tegowangi. Pemilihan hutan pinus kawasan Besuki karena lokasinya yang berdekatan dengan Dholo. Sedangkan Kelud dipilih karena merupakan ikon wisata alam Kabupaten Kediri.

\section{Storyboard}

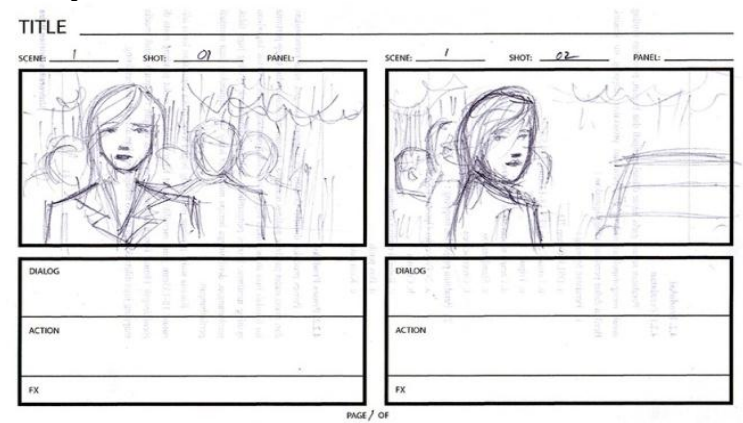

Adegan 1. Pemeran utama di tengah hiruk pikuk kota.

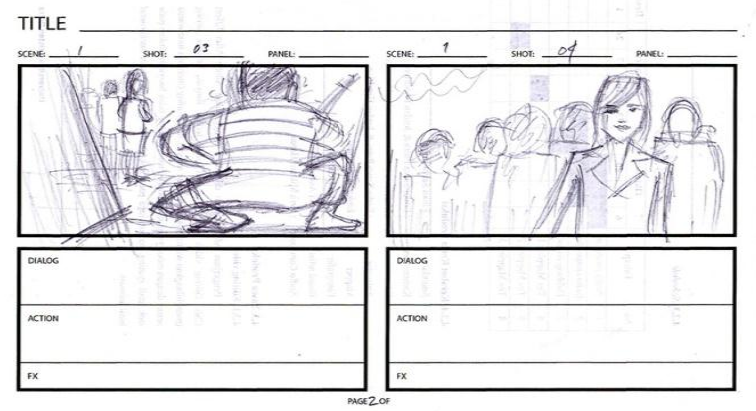

Adegan 1. Pemeran utama melihat sang anak, tergelitik untuk melihat lebih jelas. 
TITLE
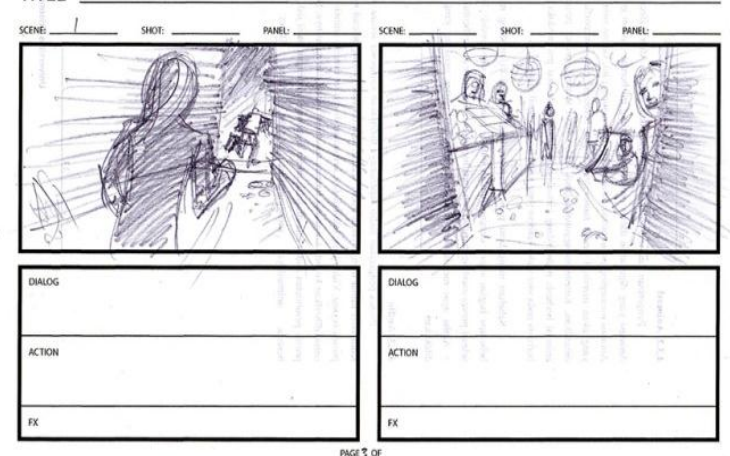

Adegan 2. Mengejar sang anak, masuk ke pasar malam.

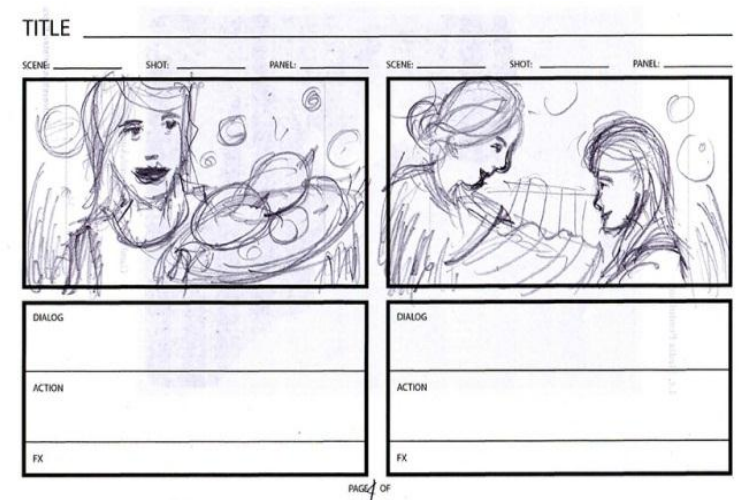

Adegan 2. Berinteraksi dengan pengusaha, pengrajin dan seniman di pasar malam.
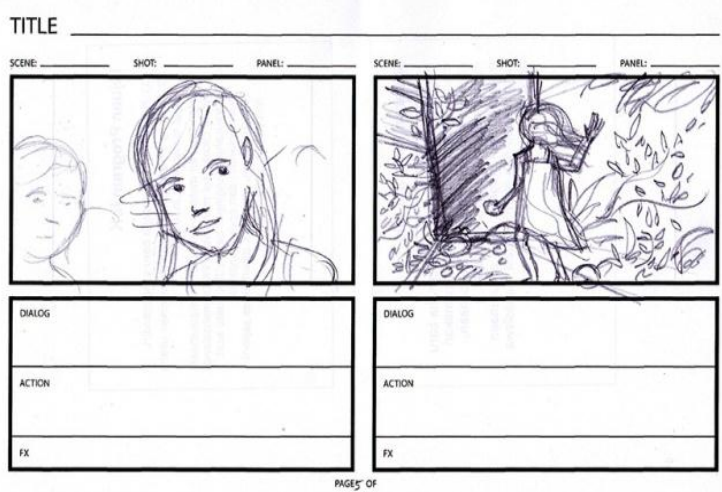

Adegan 2. Kembali mengejar sang anak.
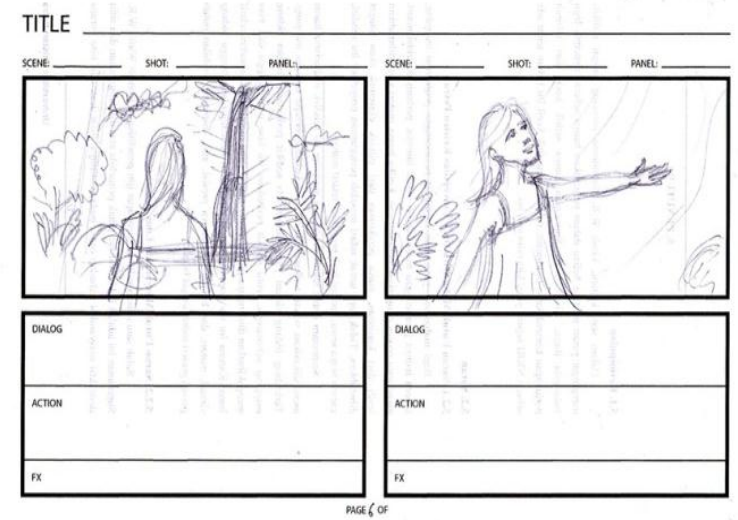

Adegan 3. Masuk ke kawasan wisata alam air terjun.

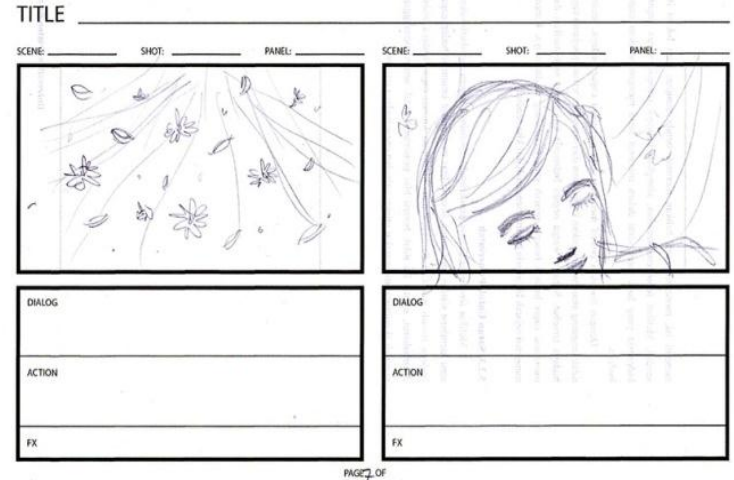

Adegan 3. Menikmati pesona alam.

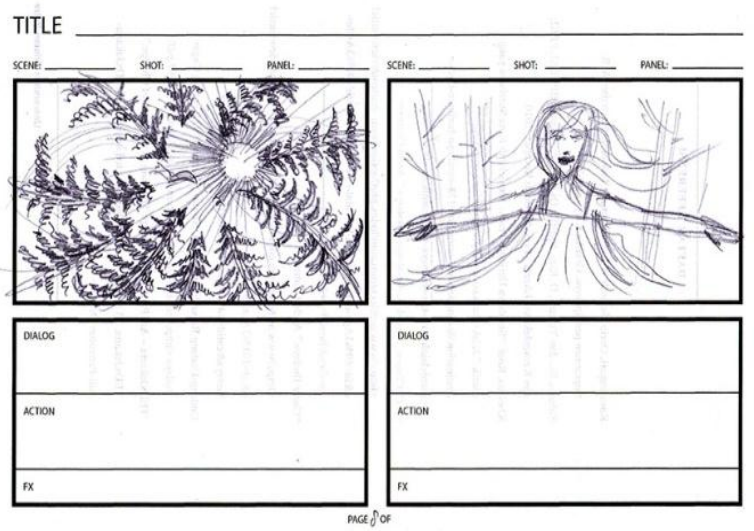

Adegan 3. Menikmati pesona alam hutan pinus.

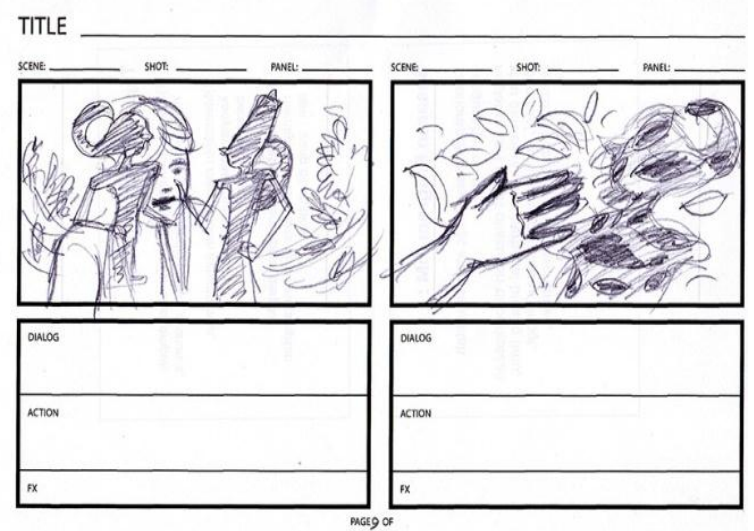

Adegan 3. Bertemu dengan seniman wayang

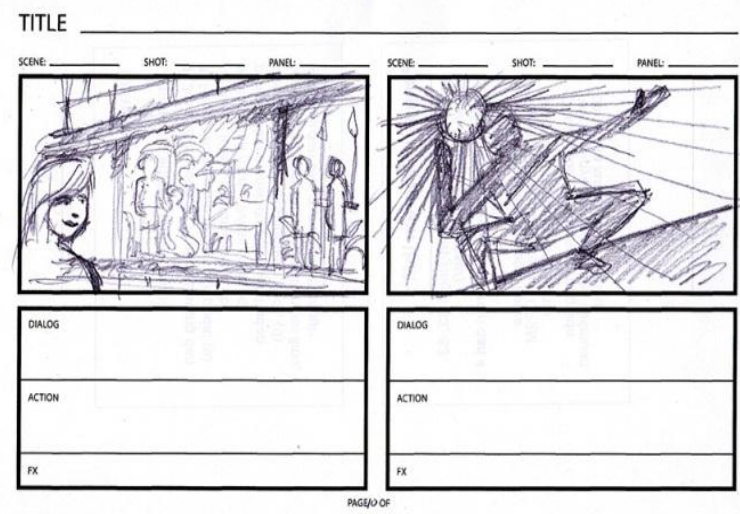

Adegan 4. Mengagumi keindahan dan kemegahan peninggalan budaya masa lalu. 
TITLE
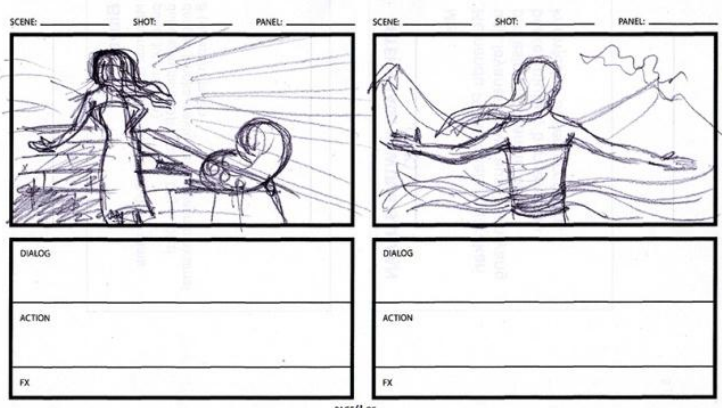

Adegan 5. Mengejar sang anak menaiki tanggan candi, takjub tiba-tiba mencapai puncak Gunung Kelud.

\section{Produksi}

Pemeran utama memberdayakan duta wisata/ budaya Kabupaten Kediri, sedangkan pemeran pembantu berasal dari anak-anak staf Dinas Pariwisata Kabupaten Kediri.

Wardrobe meminjam koleksi Batik Estri, salah satu butik pengrajin batik lokal Kabupaten Kediri. Penggunaan koleksi batik tersebut sekaligus untuk secara tidak langsung mempromosikan batik yang dihasilkan sebagai salah satu potensi pengrajin lokal.

Adegan 1 dan 2 dilaksanakan di satu lokasi (kawasan Simpang Lima Gumul.. Shot dalam adegan 3 yang menunjukkan interaksi antara pemeran utama dan dalang di hutan pinus dipindahkan ke dalam adegan 2 (pasar malam).

\section{Editing}

Pada tahap editing ini menggunakan software Adobe Premiere Pro. Dalam tahap ini, video dan audio yang telah direkam di tata agar menjadi sebuah kesatuan video.

\section{Color Grading}

Pada tahap ini proses color grading menggunakan software bawaan dari Adobe Premiere Pro.

\section{Hasil Video}

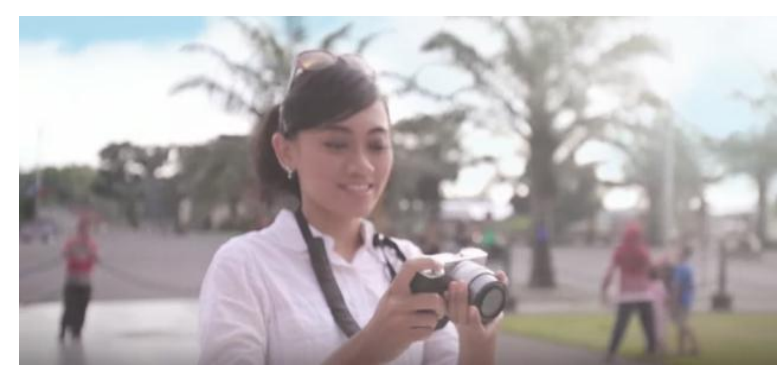

Adegan 1. Pemeran utama di tengah hiruk pikuk kota.

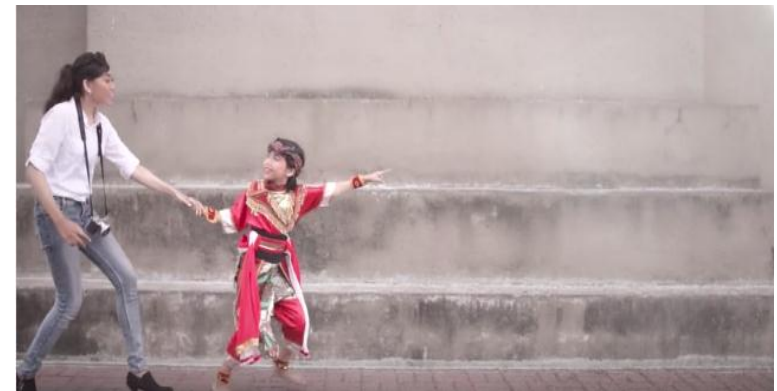

Adegan 2. Mengejar sang anak, masuk ke pasar malam

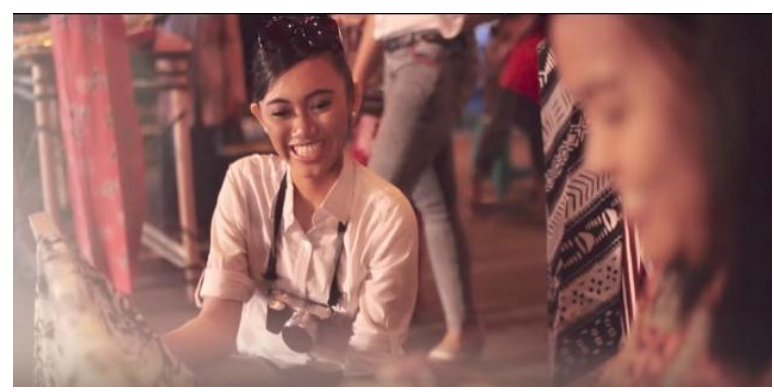

Adegan 2. Berinteraksi dengan pengusaha, pengrajin dan seniman di pasar malam.

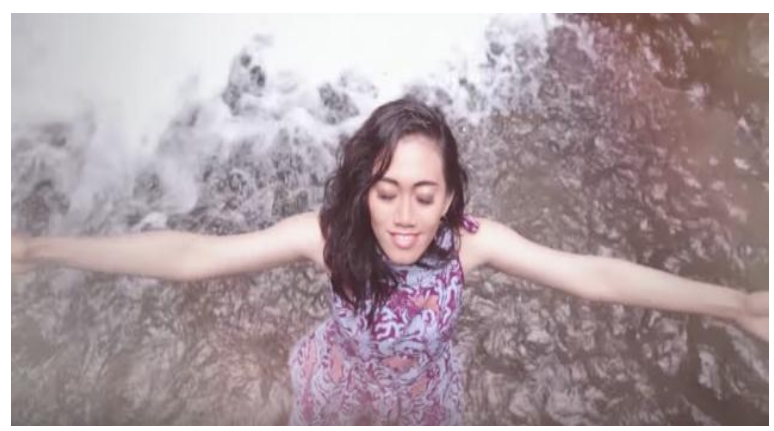

Adegan 3. Masuk ke kawasan wisata alam air terjun.

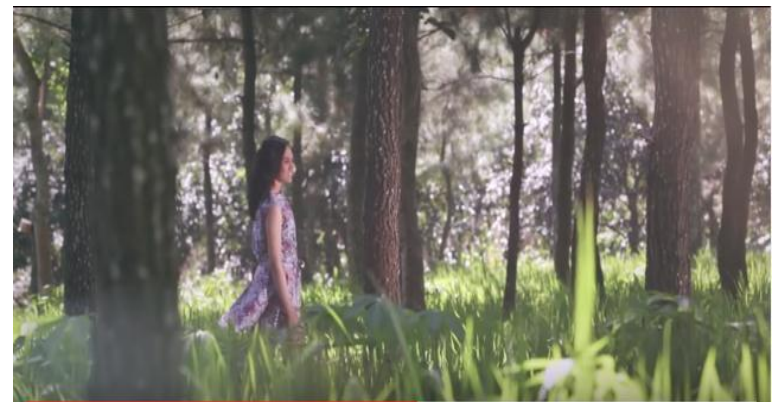

Adegan 3. Menikmati pesona alam hutan pinus.

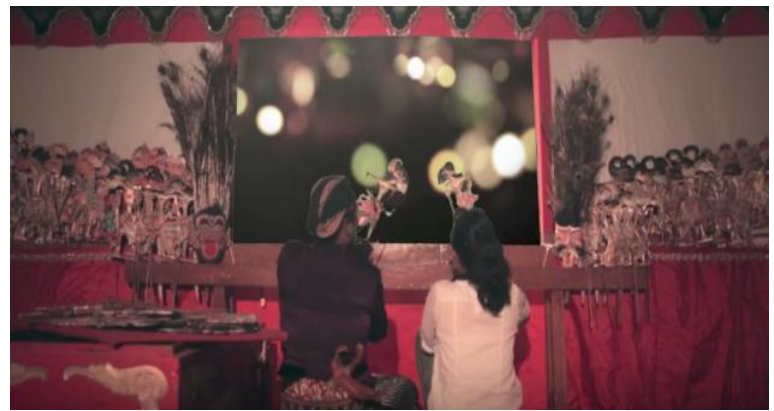

Adegan 3. Bertemu dengan seniman wayang 


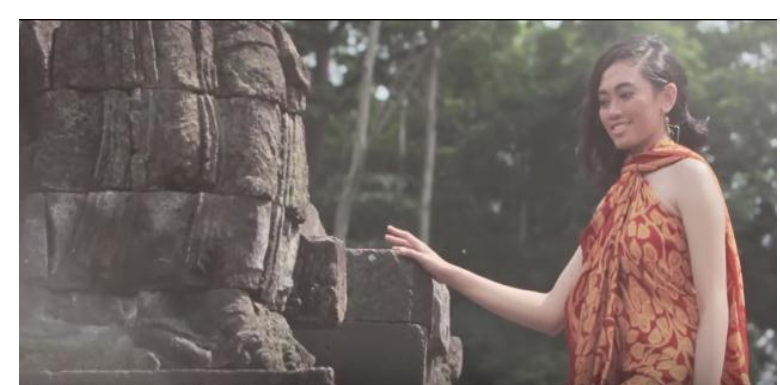

Adegan 4. Mengagumi keindahan dan kemegahan peninggalan budaya masa lalu.

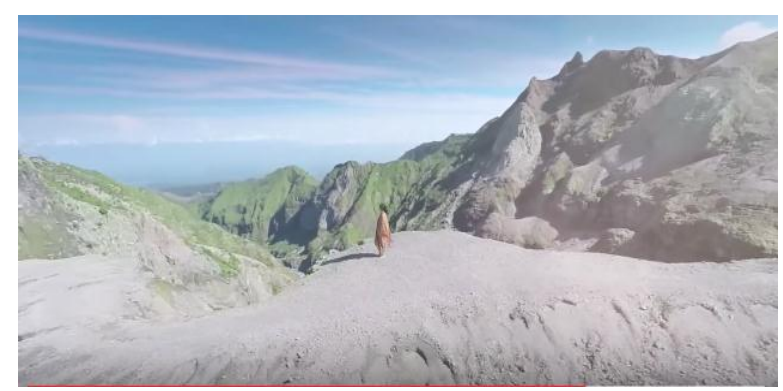

Adegan 5. Mencapai puncak Gunung Kelud.

\section{Simpulan}

Video iklan "Kediri Lagi" dari sisi muatan konten sudah berhasil dalam menampilkan potensipotensi wisata Kabupaten Kediri, sehingga sudah cukup dalam mengkomunikasikan potensi wisata yang ada.

Tetapi dari sisi eksekusi strategi komunikasi masih kurang. Narasi tidak tersampaikan dengan baik. Alur cerita yang dirancang pada tahap pra produksi tidak lagi nampak di hasil akhir video.

Beberapa faktor penyebab kegagalan tersebut adalah sebagai berikut:

- Terbatasnya dana produksi sehingga penyesuaian yang dilakukan berpengaruh terhadap alur cerita yang telah dirancang.

- Terbatasnya kemampuan pemeran dalam berakting membatasi ekspresi dan emosi yang perlu tersampaikan dalam adegan.

- Pra produki dan produksi dilakukan oleh pihak yang berbeda dan kurangnya koordinasi selama proses produksi berpengaruh terhadap alur cerita.
Selain permasalahan dari sisi strategi komunikasi, terdapat beberapa pendapat dari pemirsa yang merasa bahwa pemain utama kurang "cantik". Diskusi lebih lanjut mengungkap bahwa "cantik" menurut beberapa pemirsa tersebut identik dengan wajah berkarakter peranakan melayu dengan caucasian (Indo). Terkait hal tersebut pemilihan pemeran sudah tepat karena sesuai dengan konsep awal. Tetapi beberapa pendapat tersebut bermanfaat dalam menggali insight pemirsa yang ternyata masih belum siap menerima estetika lokal.

Berdasarkan penelusuran di Youtube diperoleh 2 akun yang menayangkan video iklan "Kediri Lagi”. Kedua akun tersebut tidak mencantumkan nama Dinas Pariwisata dan tidak disertai logo "Kediri Lagi". Hal tersebut berdampak pada proses komunikasi. Pemirsa dapat beranggapan bahwa video yang ditayangkan bukan merupakan media resmi dalam rangkaian aktifitas destination branding Kabupaten Kediri, sehingga dapat mengurangi kemampuan video dalam mempersuasi pemirsa.

\section{Daftar Pustaka}

Arsyad, Azhar. (2006). Media Pembelajaran. Jakarta: Raja Grafindo Persada.

Kaplanidou, K., and C. Vogt. (2003). Destination branding: Concept and measurement. Working paper, Michigan State University.

Kotler, Philip dan Armstrong, Gary. (2003). DasarDasar Pemasaran. Diterjemahkan oleh Alexander Sindoro. Jakarta: PT. Indeks, 2003.

McDaniel, Lamb Hair. (2001). Pemasaran. Edisi Pertama. Jakarta: Salemba Empat.

M.Suyanto. (2005), Multimedia" Alat Untuk Meningkatkan Keunggulan Bersaing", Yogyakarta: Andi.

Ritchie, J. R. Brent, and Robin J. B. Ritchie (1998). The Branding of Tour-ism Destinations: Past Achievements and Future Challenges". Proceedings of the 1998 Annual Congress of the International Association of Scientific Experts in Tourism, Destination Marketing: Scopes and Limitations, edited by Peter Keller. Marrakech, Morocco: International Association of Scientific Experts in Tourism, 89-116. 